\title{
ESTIMATING POLLUTANT REMOVAL REQUIREMENTS FOR LANDFILLS IN THE UK: II. MODEL DEVELOPMENT
}

\author{
D. H. Hall ${ }^{1}$, D. Drury ${ }^{1}$, J. R. Gronow ${ }^{2}$, A. Rosevear ${ }^{3}$, S. J. T. Pollard ${ }^{2}$ and R. Smith²*
}

\begin{abstract}
${ }^{1}$ Golder Associates (UK) Ltd., Attenborough House, Browns Lane Business Park, Stanton-on-theWolds, NG12 5BL, UK

${ }^{2}$ Integrated Waste Management Centre, Sustainable Systems Department, School of Applied Sciences, Cranfield University, MK43 0AL, UK

${ }^{3}$ Environment Agency, Kings Meadow House, Kings Meadow Road, Reading, RG1 8DQ, UK.

* Corresponding author Tel +44 (0)1234 754963; Fax +44 (0)1234 376171; e-mail r.smith1@cranfield.ac.uk
\end{abstract}

\begin{abstract}
A modelling methodology using a leachate source term has been produced for estimating the timescales for achieving environmental equilibrium status for landfilled waste. Results are reported as the period of active management required for modelled scenarios of non-flushed and flushed sites for a range of pre-filling treatments. The base scenario against which results were evaluated was raw municipal solid waste (MSW) for which only cadmium failed to reach equilibrium. Flushed raw MSW met our criteria for stabilisation with active leachate management for 40 years, subject to each of the leachate species being present at or below their average UK
\end{abstract}


concentrations. Stable non-reactive wastes, meeting EU waste acceptance criteria, fared badly in the non-flushed scenario, with only two species stabilising after a management period within 1000 years and the majority requiring >2000 years of active leachate management. The flushing scenarios showed only a marginal improvement, with arsenic still persisting beyond 2000 years management even with an additional $500 \mathrm{~mm} \mathrm{y}^{-1}$ of infiltration. The stabilisation time for mechanically sorted organic residues (without flushing) was high, and even with flushing, arsenic and chromium appeared to remain a problem. Two mechanical biological treatment (MBT) scenarios were examined, with medium and high intensity composting. Both were subjected to the non-flushing and flushing scenarios. The non-flushing case of both options fell short of the basic requirements of achieving equilibrium within decades. The intense composting option with minimal flushing appeared to create a scenario where equilibrium could be achieved. For incinerator bottom ash (raw and subjected to various treatments), antimony, copper, chloride and sulphate were the main controls on achieving equilibrium, irrespective of treatment type. Flushing at higher flushing rates $\left(500 \mathrm{~mm} \mathrm{y}^{-1}\right)$ failed to demonstrate a significant reduction in the management period required.

Keywords: Equilibrium; completion; emissions; MSW

\section{INTRODUCTION}

This work presents the second of a series of three companion papers. The first manuscript presented a leachate modelling benchmark study and review of treatment technologies [1] in relation to removing landfill pollutants and achieving environmental equilibrium status. Equilibrium is defined here as that state when emissions from a landfill site occur at a rate that 
allows sufficient natural attenuation in the surrounding environment to prevent environmental harm, so management is no longer required. To embody the principles of sustainability, equilibrium can only be achieved when the management period (post-closure when the site has ceased accepting waste for disposal) is measured in decades rather than centuries. The hydrogeological scenario used as a basis for calculations is depicted in Figure 1.

\section{MODELLING METHODOLOGY}

\section{Modelling approach and objectives}

This section provides further information on the methodology; the details have been provided in the review of treatment technologies provided in the first manuscript. The post processing capabilities of GoldSim [2] allowed multivariate analysis of the results, which is essential in order to correlate the length of aftercare period with long-term groundwater impacts. Apart from the aftercare period, all other inputs to the model were set as single values only.

Essentially the aftercare period was defined as a variable and the model was run allowing this period to vary between 3 years and 2000 years. During each iteration (each using a different aftercare period) the maximum groundwater concentration for each of the contaminants modelled was recorded and then plotted against aftercare time. In this way, the management time period needed to achieve the water quality standard could be estimated. Any model run that resulted in a contaminant requiring a management period greater than 2000 years was simply recorded as $>2000$. 
In the model it was assumed that leachate pumping at the site continued throughout the aftercare period maintaining leachate heads at $1 \mathrm{~m}$. Once management ceases, leachate heads were allowed to vary. The methodology for this was based on the water balance model incorporated in LandSim 2.5 [3]. Leachate levels were expected to increase as a result of cap infiltration and cap deterioration despite the fact that the leakage rate was likely to increase markedly as a result of degradation of the liner system. No account was taken of the prospect of cap breakout of leachate as a result of a build-up of leachate head after the end of management control. It was assumed that this possibility was likely to be a further and semi-independent site-specific control on the duration of site management.

The European Landfill Directive [4] seeks to minimise leachate production by limiting rainfall infiltration and groundwater inflow. It has been shown that appreciable flushing rates are important for achieving landfill stabilisation [5]. Therefore, simulations were also run as flushing systems with 200 or $500 \mathrm{~mm}$ of additional infiltration, to determine the implications for aftercare periods. This recirculation ceases at the time management control ends. The receptors for the various contaminants were selected as the downgradient boundary of the site for List II or nonlisted substances [6] and the base of the unsaturated zone for List I substances.

Note that, on a site-specific basis, the water quality standards used may not be appropriate, as they may be too high (e.g. if the site is in a sensitive location) or too low (e.g. where background levels already exceed these values and the location is not sensitive). Also, certain species, such as zinc, are only found in high concentrations in leachates that are acetogenic; concentrations often fall below the relevant water quality standards once the waste becomes fully anaerobic. In this instance, the concentration was modelled at its higher aerobic concentration. It must be stressed 
that there will be situations where the leachate strengths will be higher than those used in the model, and where less attenuating capacity is available. However, the modelling was undertaken on the basis of mean leachate concentrations (not ranges) and is based on a 50th percentile result and not a 95th percentile (which would be the typical percentile used for a risk assessment). For each scenario and each contaminant, the modelling approach allowed for an estimation of the leachate strength when management control can end and groundwater impacts are acceptable (i.e. less than the Water Quality Standard (WQS)).

\section{Model inputs}

In all cases the landfill was assumed to be composite lined with a HDPE capping system. Infiltration into the open waste mass prior to capping was assumed to be $250 \mathrm{~mm} \mathrm{y}^{-1}$ (taken over a ten year period) reducing to $50 \mathrm{~mm} \mathrm{y}^{-1}$ on capping. Infiltration was then allowed to increase from $50 \mathrm{~mm} \mathrm{y}^{-1}$ to $140 \mathrm{~mm} \mathrm{y}^{-1}$ between 250 and 1000 years to simulate degradation of the cap. Single value inputs for the generic site modelled are provided in Tables 1 to 6 below.

Conservative retardation factors (identical to those used for the UK contribution to the derivation of EU Waste Acceptance Criteria (WAC) were used [7]. Ammoniacal nitrogen was not included in the WAC, so a typical value of $0.51 \mathrm{~kg}^{-1}$ was chosen. It was assumed that biodegradation of ammoniacal nitrogen did not occur.

There is some uncertainty about the long term viability of kappa values (first order decay constants) as an input variable to the modelling that has been undertaken. Work is currently underway in the UK to derive additional waste characterisation information that will help to 
understand the short-term variability of kappa for some of the contaminants of interest. Only by looking at long-term leachate quality data from landfills where some realistic estimate of the liquid/solid (L/S) ratio can be made, will any real advance in our understanding of this variable be achieved. We consider that it remains, at this time, the best method of estimating long-term leaching behaviour, but it is unlikely to represent the perfect solution and further advances in this area should be made over coming years as more date become available.

\section{Leachate source term}

The main contaminants modelled were those that are included in the EU WAC, although the inclusion of ammoniacal nitrogen was necessary, as for some waste streams it will represent one of the key contaminants in relation to its concentration in leachate and its various water quality standards. The inclusion of ammoniacal nitrogen within the list of contaminants modelled required the derivation of a nominal (and certainly non-statutory) WAC for ammonia.

Data relating to initial leachate concentrations came from a variety of sources. For the Mechanical Biological Treatment (MBT) residues and incinerator bottom ash, data were derived from published research [8]. For those model runs relating to WAC values, $\mathrm{C}_{0}$ was taken to be the initial flush from a standard column test equating to a L/S ratio of approximately $0.051 \mathrm{~kg}^{-1} \mathrm{back}$ calculated from the published WAC. Additional data were drawn from corporate knowledge and judgement.

The initial leachate concentrations used for the modelling of municipal solid waste (MSW) and treated MSW (or closely allied wastes) are shown in Table 6, and those for incinerator bottom 
ash (both raw and treated) are shown in Table 7. It should be noted that suitable leachate source terms were not identified for all of the ten processes discussed.

The column in Table 6 entitled 'Stable Non-Reactive' relates solely to the $\mathrm{C}_{0}$ values derived from the WAC for that waste that could be placed in a non-hazardous landfill in a separate cell. The implied assumption was that the entire waste was deposited at the maximum concentration of each species. The likelihood of this occurring is very low, but given that individual species were being examined it did provide an insight into which species are likely to result in the need to extend aftercare periods from the processes included.

\section{Model results}

Tables 9, 10 and 11 show a summary of the results of the modelling exercise simply indicating, for each waste stream, each landfill management option and each species with the number of years required to achieve equilibrium status. For each scenario the model was run using what might be regarded as a standard management option (i.e. the waste remains uncapped during the filling sequence and is then capped). In addition, a flushing scenario where infiltration is increased during the management period has been modelled. Whether this is achieved by irrigation beneath the cap, by not having a cap, by removing the cap, or via treated leachate recirculation is, to an extent, incidental for modelling purposes.

True equilibrium status for a landfill is only achieved after every contaminant has reached equilibrium status. The final row in each table picks up the longest period defined by any species within the landfill and therefore highlights the one that equilibrium status is dependent upon. 
Table 8 examines raw MSW and a synthetic leachate derived to represent a site filled with waste at its maximum WAC for stable non-reactive waste. This is a slightly fictitious scenario as it is highly unlikely that wastes infilling a site would all equal the relevant WAC. However, it is conceivable that a process waste might be consistently close to the limit for one of the WAC species.

The raw MSW waste in the basic scenario (i.e. one where the waste is placed, capped and leachate generation minimised) formed the base case. Somewhat surprisingly this scenario contained only one contaminant that failed the general criteria of equilibrium status. It must be noted however that the compliance concentration for cadmium was taken as the drinking water standard and not the Minimum Reporting Value (MRV), albeit that the compliance point was taken as the base of the unsaturated zone. The MRV is the value that is normally applied to List 1 Substances to determine whether their presence is discernible or not, and is enshrined in the UK groundwater risk assessment methodology [9]. If the compliance water quality standard is taken as the MRV, the time for cadmium to reach equilibrium status increases to slightly over 2000 years. The option of disposing of raw MSW to landfill is unlikely to remain as the Landfill Directive seeks to reduce the volume of biodegradable MSW being disposed of to landfill.

The flushed raw MSW met the criteria of stabilisation at 40 years, subject to each of the leachate species being present at or below their average UK concentrations. After this time it is interesting to note that landfill gas generation would also have ceased (or at least be below the point at which meaningful management could be applied), so the requirements of equilibrium status would have been met. 
Stable non-reactive wastes meeting the WAC performed badly in the non-flushing scenario, with only two species stabilising within 1000 years and the majority taking in excess of 2000 years. The flushing scenarios showed only a marginal improvement, with arsenic still persisting beyond 2000 years with an additional $500 \mathrm{~mm} \mathrm{y}^{-1}$ of infiltration.

Table 9 shows the results for mechanically and biologically treated waste. Mechanically Sorted Organic Residues (MSOR) generates a waste that is high in contaminants and has high ammonia loading. As such, its stabilisation time (without flushing) was high, and even with flushing, arsenic and chromium remained a problem. In this case cadmium did not appear to be an issue at either of its WQSs.

Two MBT cases were examined, one with medium intensity composting and one with highly intensive composting. Both were subjected to the non-flushing and flushing scenarios. The non-flushing case of both fell short of the basic requirements of equilibrium status within decades. However, the intense composting option with some minimal flushing appeared to create a scenario where equilibrium status could be achieved. Cadmium met the MRV at around 400 years in the flushed scenario.

The final set of results (Table 10) relate to incinerator bottom ash (raw and subjected to various treatments). Antimony, copper, chloride and sulphate appeared to be the main controls in achieving equilibrium status of this waste stream, irrespective of the treatment type. Flushing at higher rates $\left(500 \mathrm{~mm} \mathrm{y}^{-1}\right)$ failed to make a significant reduction in the management period required. It may be that the source term used was selected with conservatism and that a greater 
familiarity with the material would generate lower mean values of the key contaminants. What is clear is that bottom ash on its own will remain a challenge.

\section{Leachate source concentrations at time of equilibrium}

One of the objectives of this work was to determine a test to assist in defining when waste has reached equilibrium status. Leachate quality itself should give an indication of the status of the waste, and it was originally thought that a series of leachate quality criteria could be developed that could be used to define equilibrium status (with respect to leachate). Leachate source concentrations when equilibrium status was attained (based on the results presented in Tables 9, 10, and 11) were extracted from the data and are presented in Tables 12, 13 and 14. It is clear that there is no single leachate value that dictates equilibrium. Degradation of the liner and capping systems causes considerable complexity of the relationship between leachate quality with time, transient groundwater quality, and equilibrium.

Overall it would appear from the work undertaken that intensively composted MBT residues that undergo flushing within a landfill will provide one means of achieving equilibrium status. MBT is gaining in popularity in the UK and Europe. Reports that MBT residues have a low permeability do raise some concern. It would not be feasible to irrigate a material with a permeability value of $1 \times 10^{-10} \mathrm{~m} \mathrm{~s}^{-1}$ at a rate of more that $3 \mathrm{~mm} \mathrm{y}^{-1}$. A permeability value of greater than $6 \times 10^{-9} \mathrm{~m} \mathrm{~s}^{-1}$ would be required to allow intensively composted MBT residues to meet the requirements of our definition of sustainable landfill (in relation to leachate). 
The result of this is that rather than generating a specific time to achieve equilibrium status, the best that can be achieved is the definition of a broad time scale over which equilibrium status may be achieved. It is further cautioned that there remains some considerable uncertainty with these results and they must be regarded as tentative.

\section{CONCLUSIONS}

This work has demonstrated that there is no simple relationship between landfill leachate quality and equilibrium status. Equilibrium status is achievable for MBT treated waste with intensive composting, the residues from which are then landfilled. There is a wide range of reported literature values for the permeability of these waste streams and further work is required to assess their actual permeability which is likely to be the limiting factor for achieving equilibrium status. Further work is also needed on the composition and leaching potential of treated waste streams. Data for pyrolysis and gasification processes in particular is lacking, though these are not likely to become dominant strategic options for waste management in the foreseeable future. Data is also lacking for the anaerobic digestion of specific waste streams and there are a growing number of these facilities in the UK in common with Europe.

The achievement of equilibrium status for an entire landfill is site-specific and ultimately factors such as size of site and depth of waste are likely to be important. The behaviour of wastes at deep (>50m) landfills is uncertain and appropriate L/S ratios may not be achieved even with leachate recirculation. Robust leachate collection systems in such sites will be essential.

This requires an evaluation of landfill management practice at current landfills so as to promote the achievability of equilibrium. For pre-Landfill Directive sites there is likely to be a legacy of long active management periods taking centuries rather than decades. Some of these sites 
may ultimately fall under the contaminated land legislative regime. A third manuscript [9]

considers the policy and operational implications of this work.

\section{ACKNOWLEDGEMENTS}

This work was jointly funded by the Environment Agency for England and Wales and

ESART. This paper is published with permission. Opinions expressed are the authors' alone.

\section{REFERENCES}

1. Hall D.H., Drury D., Gronow J.R., Rosevear A., Pollard S.J.T. and Smith R., Estimating pollutant removal requirements for landfills in the UK: I. Benchmark study and characteristics of waste treatment technologies. Environmental Technology, Submitted (2006).

2. GoldSim Technology Group, GoldSim modelling software. http://www.goldsim.com/. (2005).

3. Drury D., Hall D.H. and Dowle J., The development of LandSim 2.5. National Groundwater and Contaminated Land Centre report GW/03/09. Environment Agency, Bristol, (2003).

4. Council of the European Union, Directive 1999/31/EC on the Landfill of Waste. Official Journal of the European Communities, L 182, 1-19 (1999).

5. Buchanan D., Clark C.F., Ferguson N.S. and Kenny M.J., Hydraulic characteristics of wet-pulverised municipal waste. J CIWEM, 15, 14-20 (2001).

6. Council of the European Communities, Council Directive of 17 December 1979 on the protection of groundwater against pollution caused by certain dangerous substances (80/68/EEC). Official Journal of the European Communities L20, 26/01/1980, 43-48 (1980).

7. Hall D. and Drury D., Landfill Directive waste acceptance criteria: a perspective of the UK's contribution to the Technical Adaptation Committee, Modelling Subgroup. In: Proc. Waste 2002 Conf. Integrated Waste Management and Pollution Control: Research, Policy and Practice, Stratford-upon-Avon, UK, pp. 72-81 (2002).

8. Bone B.D., Knox K., Picken A. and Robinson H.D., The effect of mechanical and biological pretreatment on landfill leachate quality. In: Proceedings Sardinia 2003, Ninth International Waste Management and Landfill Symposium, S. Margherita di Pula, Cagliari, Italy (2003).

9. Hall D.H., Drury D., Gronow J.R., Pollard S.J.T. and Smith R., Estimating pollutant removal requirements for landfills in the UK: III. Policy analysis and operational implications. Environmental Technology, Submitted (2006).

10. Environment Agency, The development of LandSim 2.5. National Groundwater and Contaminated Land Centre report GW/03/09. Environment Agency, Bristol, (2003).

11. Council of the European Union, Decision 2003/33/EC establishing criteria and procedures for the acceptance of waste at landfills pursuant to Article 16 of and Annex II to Directive 1999/31/EC. Official Journal of the European Communities, L11, 27-49 (2003). 


\section{FIGURE AND TABLE TITLE LIST}

Figure 1. The basic hydrogeological scenario for the basis of calculations.

Table 1. Values describing basal lining system.

Table 2. Physical waste properties used in modelling.

Table 3. Kappa values defining the rate of source term concentration decline.

Table 4. Values describing unsaturated and saturated zones.

Table 5. Values of contaminant species specific parameters.

Table 6. Initial leachate concentrations for MSW and allied waste streams ( $\left.\mathrm{mg} \mathrm{l}^{-1}\right)$.

Table 7. Initial leachate concentrations for MSW incinerator ash ( $\left.\mathrm{mg} \mathrm{l}^{-1}\right)$.

Table 8. Results of the modelling management time for MSW and stable non-reactive wastes.

Table 9. Results of the modelling management time for mechanically and biologically treated wastes.

Table 10. Results of the modelling management time for incinerator bottom ash.

Table 11. Leachate concentrations at equilibrium status for MSW and stable non-reactive wastes.

Table 12. Leachate concentrations at equilibrium status for mechanically and biologically treated wastes.

Table 13. Leachate concentrations at equilibrium status for incinerator bottom ash. 
Figure 1.

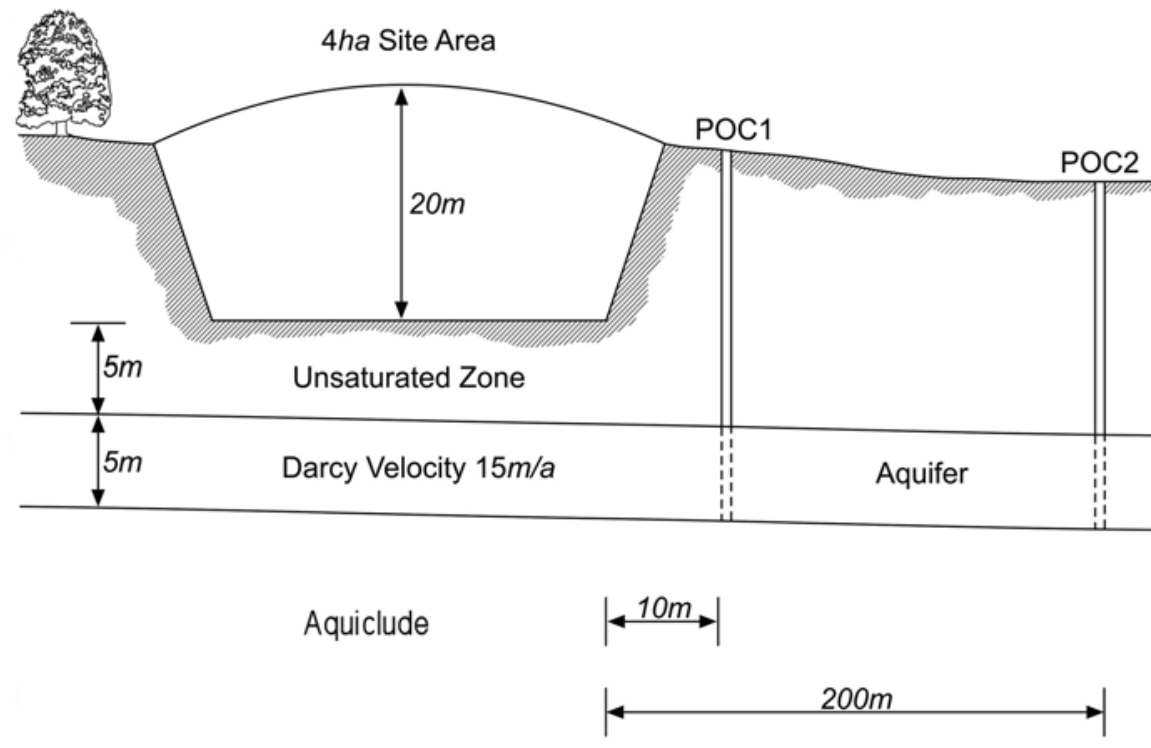


Table 1. Values describing basal lining system.

\begin{tabular}{ll}
\hline Parameter - Flexible membrane liner & Parameter value \\
\hline Area of pinholes & $2.55 \mathrm{~mm}^{2}$ \\
Area of holes & $52.5 \mathrm{~mm}^{2}$ \\
Area of tears & $5050 \mathrm{~mm}^{2}$ \\
Number of pinholes & start $=0$, end $=25$ \\
Number of holes & start $=0$, end $=5$ \\
Number of tears & start $=0$, end $=0.1$ \\
Contact coefficient for leakage calculations & 0.68 \\
Contact coefficient for calculation of radius of & 0.435 \\
wetted area & \\
Mineral component & \\
Clay permeability & $1 \mathrm{E}-9 \mathrm{~m} \mathrm{~s}^{-1}$ \\
Mineral liner porosity & 0.3 \\
Mineral liner density & $1800 \mathrm{~kg} \mathrm{~m}^{3}$ \\
Liner thickness & $1 \mathrm{~m}$ \\
\hline
\end{tabular}


Table 2. Physical waste properties used in modelling.

\begin{tabular}{ll}
\hline Parameter & Parameter value \\
\hline Waste density & Dependent on waste type. \\
Waste porosity & 0.3 \\
Waste field capacity & 0.3 \\
\hline
\end{tabular}


Table 3. Kappa values defining the rate of source term concentration decline.

\begin{tabular}{ll}
\hline Contaminant species & Kappa value $\left(\mathrm{kg} \mathrm{l}^{-1}\right)$ \\
\hline Antimony $(\mathrm{Sb})$ & 0.11 \\
Arsenic $(\mathrm{As})$ & 0.03 \\
Barium $(\mathrm{Ba})$ & 0.15 \\
Cadmium $(\mathrm{Cd})$ & 0.35 \\
Chromium $(\mathrm{Cr})$ & 0.18 \\
Copper $(\mathrm{Cu})$ & 0.57 \\
Mercury $(\mathrm{Hg})$ & 0.05 \\
Lead $(\mathrm{Pb})$ & 0.27 \\
Molybdenum $(\mathrm{Mo})$ & 0.35 \\
Nickel $(\mathrm{Ni})$ & 0.29 \\
Zinc $(\mathrm{Zn})$ & 0.28 \\
Selenium $(\mathrm{Se})$ & 0.38 \\
Fluoride $(\mathrm{F})$ & 0.22 \\
Sulphate $\left(\mathrm{SO} \mathrm{H}_{4}\right)$ & 0.33 \\
Chloride $(\mathrm{Cl})$ & 0.57 \\
NH &
\end{tabular}

Source: Data used for EU WAC modelling [10] 
Table 4. Values describing unsaturated and saturated zones.

\begin{tabular}{ll}
\hline Parameter & Parameter value \\
\hline Thickness of the unsaturated zone & $5 \mathrm{~m}$ \\
$\begin{array}{l}\text { Distance from edge of landfill to first saturated zone point of } \\
\text { compliance (POC1) }\end{array}$ & $10 \mathrm{~m}$ \\
$\begin{array}{l}\text { Distance from edge of landfill to second saturated zone point of } \\
\text { compliance (POC2) }\end{array}$ & $200 \mathrm{~m}$ \\
Darcy flux & $15 \mathrm{~m} \mathrm{yr}^{-1}$ \\
Aquifer porosity & 0.3 \\
Aquifer thickness & $5 \mathrm{~m}$ \\
Aquifer density & $2000 \mathrm{~kg} \mathrm{~m}^{3}$ \\
\hline
\end{tabular}


Table 5. Values of contaminant species specific parameters.

\begin{tabular}{|c|c|c|c|}
\hline $\begin{array}{l}\text { Contaminant } \\
\text { species }\end{array}$ & $\begin{array}{l}\text { Liner, unsaturated } \\
\text { zone and saturated } \\
\text { zone partition } \\
\text { coefficient }\left(\mathrm{kg}^{-1}\right)\end{array}$ & $\begin{array}{l}\text { Water Quality } \\
\text { Standard (mg 1-1) }\end{array}$ & $\begin{array}{l}\text { Location of receptor where } \\
\text { water quality standard } \\
\text { must be achieved }\end{array}$ \\
\hline Antimony (Sb) & 5 & 0.005 & Receptor 1 \\
\hline Arsenic (As) & 50 & 0.01 & Receptor 1 \\
\hline Barium (Ba) & 2 & 0.7 & Receptor 1 \\
\hline $\begin{array}{l}\text { Cadmium } \\
\text { (Cd) }\end{array}$ & 20 & 0.005 & Base of unsaturated zone \\
\hline $\begin{array}{l}\text { Chromium } \\
(\mathrm{Cr})\end{array}$ & 100 & 0.05 & Receptor 1 \\
\hline Copper $(\mathrm{Cu})$ & 14 & 0.05 & Receptor 1 \\
\hline Mercury (Hg) & 100 & 0.001 & Base of unsaturated zone \\
\hline Lead $(\mathrm{Pb})$ & 50 & 0.01 & Receptor 1 \\
\hline $\begin{array}{l}\text { Molybdenum } \\
\text { (Mo) }\end{array}$ & 10 & 0.07 & Receptor 1 \\
\hline Nickel (Ni) & 50 & 0.02 & Receptor 1 \\
\hline Zinc $(\mathrm{Zn})$ & 30 & 0.1 & Receptor 1 \\
\hline Selenium (Se) & 5 & 0.01 & Receptor 1 \\
\hline Fluoride $(\mathrm{F})$ & 0 & 1.5 & Receptor 2 \\
\hline Sulphate $\left(\mathrm{SO}_{4}\right)$ & 0 & 250 & Receptor 2 \\
\hline Chloride (Cl) & 0 & 250 & Receptor 2 \\
\hline $\mathrm{NH}_{4}$ & 0.5 & 0.5 & Receptor 2 \\
\hline
\end{tabular}


Table 6. Initial leachate concentrations for MSW and allied waste streams ( $\left.\mathrm{mg} \mathrm{l}^{-1}\right)$.

\begin{tabular}{|c|c|c|c|c|c|}
\hline $\begin{array}{l}\text { Waste Stream } \\
\text { Treatment } \\
\text { Reference }\end{array}$ & $\begin{array}{c}\text { MSOR } \\
{[8]}\end{array}$ & $\begin{array}{c}\text { MBT } \\
\text { Intensive } \\
{[8]}\end{array}$ & $\begin{array}{c}\text { MBT } \\
\text { Medium } \\
{[8]}\end{array}$ & $\begin{array}{c}\text { MSW } \\
\text { Raw } \\
\text { LandSim } \\
{[10]}\end{array}$ & $\begin{array}{c}\text { Stable non-reactive } \\
\text { None } \\
\text { WAC [11] }\end{array}$ \\
\hline \multicolumn{6}{|l|}{ Species } \\
\hline $\mathrm{Sb}$ & $x$ & $X$ & $X$ & $X$ & 0.15 \\
\hline As & 0.1 & 0.006 & 0.05 & 0.013 & 0.3 \\
\hline $\mathrm{Ba}$ & $X$ & $X$ & $X$ & $X$ & 20 \\
\hline $\mathrm{Cd}$ & 0.0005 & 0.003 & 0.02 & 0.01 & 0.3 \\
\hline $\mathrm{Cr}$ & 5 & 0.1 & 0.3 & 0.18 & 2.5 \\
\hline $\mathrm{Cu}$ & 0.5 & 0.2 & 0.35 & 0.1 & 30 \\
\hline $\mathrm{Hg}$ & 0.0001 & 0.0001 & 0.0001 & 0.00009 & 0.03 \\
\hline $\mathrm{Pb}$ & 0.05 & 0.04 & 0.3 & 0.17 & 3 \\
\hline Мo & $X$ & $X$ & $X$ & $X$ & 3.5 \\
\hline $\mathrm{Ni}$ & 0.5 & 0.1 & 0.4 & 0.24 & 3 \\
\hline $\mathrm{Zn}$ & 0.5 & 0.2 & 1.5 & 5.09 & 15 \\
\hline Se & $X$ & $X$ & $X$ & $X$ & 0.2 \\
\hline $\mathrm{F}$ & $x$ & $X$ & $X$ & $X$ & 40 \\
\hline $\mathrm{SO}_{4}$ & 400 & 500 & 3000 & 263 & 7000 \\
\hline $\mathrm{Cl}$ & 6000 & 2000 & 6000 & 1466 & 8500 \\
\hline $\mathrm{NH}_{4}$ & 4000 & 200 & 550 & 495 & 2000 \\
\hline
\end{tabular}

\section{Notes to Table}

X - No reliable data from UK MSW sites or literature.

Data derived from LandSim 2.5.

MSOR - Mechanically Sorted Organic Residues.

MBT - Mechanical Biological Treatment.

MSW - Raw Municipal Solid Waste.

WAC - Waste Acceptance Criteria $\mathrm{C}_{0}$ values. 
Table 7. Initial leachate concentrations for MSW incinerator ash (mg l-1).

\begin{tabular}{lccc}
\hline $\begin{array}{l}\text { Waste } \\
\text { stream }\end{array}$ & Incinerator bottom ash & \\
Treatment & Raw & Carbonated & Acid treated \\
Reference & {$[8]$} & {$[8]$} & {$[8]$} \\
\hline Species & & & \\
$\mathrm{Sb}$ & 0.025 & 0.1 & 0.2 \\
$\mathrm{As}$ & 0.001 & 0.001 & 0.001 \\
$\mathrm{Ba}$ & 1 & 0.1 & 0.25 \\
$\mathrm{Cd}$ & 0.01 & 0.01 & 0.01 \\
$\mathrm{Cr}$ & 0.01 & 0.2 & 0.03 \\
$\mathrm{Cu}$ & 5 & 5 & 10 \\
$\mathrm{Hg}$ & 0 & 0 & 0 \\
$\mathrm{~Pb}$ & 5 & 0.005 & 0.015 \\
$\mathrm{Mo}$ & 0.3 & 0.4 & 0.5 \\
$\mathrm{Ni}$ & 0.075 & 0.05 & 0.05 \\
$\mathrm{Zn}$ & 0.001 & 0.001 & 0.002 \\
$\mathrm{Se}$ & 1 & 0.05 & 0.02 \\
$\mathrm{~F}$ & 0 & 0 & 0 \\
$\mathrm{SO}_{4}$ & 500 & 2000 & 2000 \\
$\mathrm{Cl}$ & 1700 & 1700 & 1700 \\
$\mathrm{NH}$ & 10 & 10 & 15 \\
\hline
\end{tabular}


Table 8. Results of the modelling management time for MSW and stable non-reactive wastes.

\begin{tabular}{|c|c|c|c|c|c|}
\hline Waste Type & $\begin{array}{l}\text { Raw } \\
\text { MSW }\end{array}$ & Raw MSW & $\begin{array}{l}\text { Stable non- } \\
\text { reactive }\end{array}$ & $\begin{array}{l}\text { Stable non- } \\
\text { reactive }\end{array}$ & Stable non-reactive \\
\hline Treatment & None & None & None & None & None \\
\hline Scenario & Basic & $\begin{array}{l}\text { Additional } \\
200 \mathrm{~mm}^{-1} \\
\text { infiltration }\end{array}$ & Basic & $\begin{array}{l}\text { Additional } \\
200 \mathrm{~mm} \mathrm{y}^{-1} \\
\text { infiltration }\end{array}$ & $\begin{array}{c}\text { Additional } \\
500 \mathrm{~mm} \mathrm{y}^{-1} \text { infiltration }\end{array}$ \\
\hline Contaminant & \multicolumn{5}{|c|}{ Years to achieve equilibrium status } \\
\hline Antimony (Sb) & $X$ & $X$ & $>2000$ & 1350 & 700 \\
\hline Arsenic (As) & $<3$ & $<3$ & $>2000$ & $>2000$ & $>2000$ \\
\hline Barium (Ba) & $x$ & $x$ & $>2000$ & 1050 & 490 \\
\hline Cadmium (Cd) & $<3$ & $<3$ & $>2000$ & 533 & 240 \\
\hline $\begin{array}{l}\text { Chromium } \\
\text { (Cr) }\end{array}$ & $<3$ & $<3$ & 1200 & 1200 & 185 \\
\hline Copper $(\mathrm{Cu})$ & $<3$ & $<3$ & $>2000$ & 500 & 219 \\
\hline Mercury (Hg) & $<3$ & $<3$ & $>2000$ & $>2000$ & 1300 \\
\hline Lead $(\mathrm{Pb})$ & 400 & 40 & $>2000$ & 750 & 350 \\
\hline $\begin{array}{l}\text { Molybdenum } \\
\text { (Mo) }\end{array}$ & $x$ & $x$ & 1375 & 440 & 200 \\
\hline Nickel (Ni) & $<3$ & $<3$ & 1750 & 533 & 240 \\
\hline Zinc (Zn) & $<3$ & $<3$ & $>2000$ & 670 & 300 \\
\hline Selenium (Se) & $x$ & $x$ & 965 & 275 & 115 \\
\hline Fluoride (F) & $x$ & $x$ & 1700 & 665 & 250 \\
\hline Sulphate $\left(\mathrm{SO}_{4}\right)$ & $<3$ & $<3$ & 1375 & 390 & 150 \\
\hline Chloride $(\mathrm{Cl})$ & 40 & 4 & 965 & 200 & 75 \\
\hline Ammoniacal & $<3$ & $<3$ & 1100 & 130 & 50 \\
\hline $\begin{array}{l}\text { Nitrogen } \\
\left(\mathrm{NH}_{4}\right) \\
\text { Maximum } \\
\text { management } \\
\text { period } \\
\text { required in } \\
\text { scenario }\end{array}$ & 400 & 40 & $>2000$ & $>2000$ & $>2000$ \\
\hline
\end{tabular}

X - No reliable data from UK MSW sites or literature. 
Table 9. Results of the modelling management time for mechanically and biologically treated wastes.

\begin{tabular}{|c|c|c|c|c|c|c|}
\hline $\begin{array}{l}\text { Waste Type } \\
\text { Treatment } \\
\text { Scenario }\end{array}$ & $\begin{array}{c}\text { MSOR } \\
\text { None } \\
\text { Basic }\end{array}$ & $\begin{array}{c}\text { MSOR } \\
\text { None } \\
\text { Additional } \\
500 \mathrm{~mm} \mathrm{y}^{-1} \\
\text { infiltration }\end{array}$ & $\begin{array}{c}\text { MBT } \\
\text { Medium } \\
\text { Basic }\end{array}$ & $\begin{array}{c}\text { MBT } \\
\text { Medium } \\
\text { Additional } \\
200 \mathrm{~mm} \mathrm{y}^{-1} \\
\text { infiltration } \\
\end{array}$ & $\begin{array}{c}\text { MBT } \\
\text { Intense } \\
\text { Basic }\end{array}$ & $\begin{array}{c}\text { MBT } \\
\text { Intense } \\
\text { Additional } \\
200 \mathrm{~mm} \mathrm{y}^{-1} \\
\text { infiltration }\end{array}$ \\
\hline Contaminant & \multicolumn{6}{|c|}{ Years to achieve equilibrium status } \\
\hline Antimony (Sb) & $x$ & $x$ & $x$ & $x$ & $x$ & $x$ \\
\hline Arsenic (As) & $>2000$ & 1100 & $<3$ & $<3$ & $<3$ & $<3$ \\
\hline Barium (Ba) & $X$ & $X$ & $X$ & $X$ & $X$ & $X$ \\
\hline Cadmium (Cd) & $<3$ & $<3$ & 41 & $<3$ & $<3$ & $<3$ \\
\hline $\begin{array}{l}\text { Chromium } \\
\text { (Cr) }\end{array}$ & 1600 & 300 & $<3$ & $<3$ & $<3$ & $<3$ \\
\hline Copper $(\mathrm{Cu})$ & 50 & $<3$ & $<3$ & $<3$ & $<3$ & $<3$ \\
\hline Mercury $(\mathrm{Hg})$ & $<3$ & $<3$ & $<3$ & $<3$ & $<3$ & $<3$ \\
\hline Lead $(\mathrm{Pb})$ & $<3$ & $<3$ & 780 & 206 & $<3$ & $<3$ \\
\hline $\begin{array}{l}\text { Molybdenum } \\
\text { (Mo) }\end{array}$ & $X$ & $X$ & $x$ & $X$ & $X$ & $X$ \\
\hline Nickel (Ni) & 580 & 50 & 410 & 76 & $<3$ & $<3$ \\
\hline Zinc $(\mathrm{Zn})$ & $<3$ & $<3$ & 550 & 125 & $<3$ & $<3$ \\
\hline Selenium (Se) & $x$ & $X$ & $x$ & $X$ & $x$ & $x$ \\
\hline Fluoride $(\mathrm{F})$ & $x$ & $x$ & $x$ & $x$ & $x$ & $x$ \\
\hline Sulphate $\left(\mathrm{SO}_{4}\right)$ & $<3$ & $<3$ & 1050 & 184 & $<3$ & $<3$ \\
\hline $\begin{array}{l}\text { Chloride }(\mathrm{Cl}) \\
\text { Ammoniacal }\end{array}$ & 900 & 70 & 900 & 157 & 367 & 40 \\
\hline $\begin{array}{l}\text { Nitrogen } \\
\left(\mathrm{NH}_{4}\right)\end{array}$ & 1275 & 85 & $<3$ & $<3$ & $<3$ & $<3$ \\
\hline $\begin{array}{l}\text { Maximum } \\
\text { management } \\
\text { period } \\
\text { required in } \\
\text { scenario }\end{array}$ & $>2000$ & 1100 & 1050 & 206 & 367 & 40 \\
\hline
\end{tabular}

\section{Notes}

MSOR - Mechanically sorted organic residues (generally the fines)

MBT - Mechanical and Biological Treatment (Separation and composting)

Treatment - in this table it relates to the amount or intensity of the composting process.

$X$ - No reliable data from UK sites or literature. 
Table 10. Results of the modelling management time for incinerator bottom ash.

\begin{tabular}{|c|c|c|c|c|c|c|}
\hline Waste Type & $\begin{array}{l}\text { Raw } \\
\text { bottom } \\
\text { ash }\end{array}$ & $\begin{array}{c}\text { Raw } \\
\text { bottom ash }\end{array}$ & $\begin{array}{l}\text { Bottom } \\
\text { ash }\end{array}$ & Bottom ash & Bottom ash & Bottom ash \\
\hline Treatment & None & None & $\begin{array}{c}\text { Carbona } \\
\text { ted }\end{array}$ & Carbonated & Acid treated & Acid treated \\
\hline Scenario & Basic & $\begin{array}{l}\text { Additional } \\
500 \mathrm{~mm} \mathrm{y}^{-1} \\
\text { infiltration } \\
\end{array}$ & Basic & $\begin{array}{l}\text { Additional } \\
500 \mathrm{~mm} \mathrm{y}^{-1} \\
\text { infiltration }\end{array}$ & Basic & $\begin{array}{l}\text { Additional } \\
500 \mathrm{~mm} \mathrm{y}^{-1} \\
\text { infiltration }\end{array}$ \\
\hline Contaminant & \multicolumn{6}{|c|}{ Years to achieve equilibrium status } \\
\hline Antimony (Sb) & 1950 & 310 & $>2000$ & 900 & $>2000$ & 1150 \\
\hline Arsenic (As) & $<3$ & $<3$ & $<3$ & $<3$ & $<3$ & $<3$ \\
\hline Barium (Ba) & $<3$ & $<3$ & $<3$ & $<3$ & $<3$ & $<3$ \\
\hline Cadmium $(\mathrm{Cd})$ & 140 & $<3$ & 150 & $<3$ & 150 & $<3$ \\
\hline $\begin{array}{l}\text { Chromium } \\
\text { (Cr) }\end{array}$ & $<3$ & $<3$ & $<3$ & $<3$ & $<3$ & $<3$ \\
\hline Copper $(\mathrm{Cu})$ & 600 & 240 & 1750 & 240 & 2050 & 870 \\
\hline Mercury (Hg) & $\mathrm{N} / \mathrm{a}$ & $\mathrm{N} / \mathrm{a}$ & $\mathrm{N} / \mathrm{a}$ & $\mathrm{N} / \mathrm{a}$ & $\mathrm{N} / \mathrm{a}$ & $\mathrm{N} / \mathrm{a}$ \\
\hline Lead $(\mathrm{Pb})$ & 2000 & 750 & $<3$ & $<3$ & $<3$ & $<3$ \\
\hline $\begin{array}{l}\text { Molybdenum } \\
\text { (Mo) }\end{array}$ & 410 & 20 & 710 & 55 & 860 & 85 \\
\hline Nickel (Ni) & $<3$ & $<3$ & $<3$ & $<3$ & $<3$ & $<3$ \\
\hline Zinc $(\mathrm{Zn})$ & 950 & 130 & $<3$ & $<3$ & $<3$ & $<3$ \\
\hline Selenium (Se) & $<3$ & $<3$ & $<3$ & $<3$ & $<3$ & $<3$ \\
\hline Fluoride (F) & $<3$ & $<3$ & $\mathrm{~N} / \mathrm{a}$ & $\mathrm{N} / \mathrm{a}$ & $\mathrm{N} / \mathrm{a}$ & $\mathrm{N} / \mathrm{a}$ \\
\hline Sulphate $\left(\mathrm{SO}_{4}\right)$ & $<3$ & $<3$ & 1190 & 75 & 1180 & 75 \\
\hline $\begin{array}{l}\text { Chloride }(\mathrm{Cl}) \\
\text { Ammoniacal }\end{array}$ & 580 & 90 & 570 & 75 & 570 & 20 \\
\hline $\begin{array}{l}\text { Nitrogen } \\
\left(\mathrm{NH}_{4}\right)\end{array}$ & $<3$ & $<3$ & $<3$ & $<3$ & $<3$ & $<3$ \\
\hline $\begin{array}{l}\text { Maximum } \\
\text { management } \\
\text { period } \\
\text { required in } \\
\text { scenario }\end{array}$ & 2000 & 750 & $>2000$ & 900 & $>2000$ & 1150 \\
\hline
\end{tabular}


Table 11. Leachate concentrations at equilibrium status for MSW and stable non-reactive wastes.

\begin{tabular}{|c|c|c|c|c|c|}
\hline Waste type & $\begin{array}{l}\text { Raw } \\
\text { MSW }\end{array}$ & Raw MSW & $\begin{array}{l}\text { Stable non- } \\
\text { reactive }\end{array}$ & $\begin{array}{l}\text { Stable non- } \\
\text { reactive }\end{array}$ & Stable non-reactive \\
\hline Treatment & None & None & None & None & None \\
\hline & & Additional & & Additional & Additional \\
\hline Scenario & Basic & $200 \mathrm{~mm} \mathrm{y}^{-1}$ & Basic & $200 \mathrm{~mm} \mathrm{y}^{-1}$ & $500 \mathrm{~mm} \mathrm{y}^{-1}$ \\
\hline & & infiltration & & infiltration & infiltration \\
\hline Contaminant & \multicolumn{5}{|c|}{ Leachate concentration when equilibrium status is attained } \\
\hline Antimony (Sb) & $\mathrm{X}$ & $X$ & AA & 0.0082 & 0.01 \\
\hline Arsenic (As) & $\mathrm{AB}$ & $\mathrm{AB}$ & $\mathrm{AA}$ & AA & $\mathrm{AA}$ \\
\hline Barium (Ba) & $X$ & $x$ & AA & 1.1 & 1.6 \\
\hline Cadmium (Cd) & $\mathrm{AB}$ & $\mathrm{AB}$ & 0.002 & 0.02 & 0.02 \\
\hline Chromium & $\mathrm{AB}$ & $\mathrm{AB}$ & 0.61 & 0.8 & 0.824 \\
\hline Copper $(\mathrm{Cu})$ & $\mathrm{AB}$ & $\mathrm{AB}$ & AA & 0.3 & 0.3 \\
\hline Mercury (Hg) & $\mathrm{AB}$ & $\mathrm{AB}$ & $\mathrm{AA}$ & AA & 0.0022 \\
\hline Lead $(\mathrm{Pb})$ & 0.121 & 0.125 & $\mathrm{AA}$ & 0.1 & 0.109 \\
\hline $\begin{array}{l}\text { Molybdenum } \\
\text { (Mo) }\end{array}$ & $x$ & $x$ & 0.153 & 0.3 & 0.309 \\
\hline Nickel (Ni) & $\mathrm{AB}$ & $\mathrm{AB}$ & 0.051 & 2.4 & 0.248 \\
\hline Zinc (Zn) & $\mathrm{AB}$ & $\mathrm{AB}$ & $\mathrm{AA}$ & 0.8 & 0.73 \\
\hline Selenium (Se) & $x$ & $X$ & 0.0281 & 0.04 & 0.04 \\
\hline Fluoride $(\mathrm{F})$ & $X$ & $X$ & 1.8 & 3.5 & 5.28 \\
\hline Sulphate $\left(\mathrm{SO}_{4}\right)$ & $\mathrm{AB}$ & $\mathrm{AB}$ & 365.5 & 860 & 1231.5 \\
\hline Chloride $(\mathrm{Cl})$ & 1224.2 & 1401.5 & 442.4 & 1230 & 1182.5 \\
\hline $\mathrm{NH}_{4}$ & $\mathrm{AB}$ & $\mathrm{AB}$ & 49.5 & 533.9 & 504.4 \\
\hline
\end{tabular}

\section{Notes}

AA = Groundwater concentration always exceeded WQS hence leachate concentration always above equilibrium status.

$\mathrm{AB}=$ Groundwater always below WQS hence leachate always below equilibrium status. $X$ - No reliable data from UK MSW sites or literature. 
Table 12. Leachate concentrations at equilibrium status for mechanically and biologically treated wastes.

\begin{tabular}{|c|c|c|c|c|c|c|}
\hline $\begin{array}{l}\text { Waste type } \\
\text { Treatment } \\
\text { Scenario }\end{array}$ & $\begin{array}{c}\text { MSOR } \\
\text { None } \\
\text { Basic }\end{array}$ & $\begin{array}{c}\text { MSOR } \\
\text { None } \\
\text { Additional } \\
500 \mathrm{~mm} \mathrm{y}^{-1} \\
\text { infiltration }\end{array}$ & $\begin{array}{c}\text { MBT } \\
\text { Medium } \\
\text { Basic }\end{array}$ & $\begin{array}{c}\text { MBT } \\
\text { Medium } \\
\text { Additional } \\
200 \mathrm{~mm} \mathrm{y}^{-1} \\
\text { infiltration }\end{array}$ & $\begin{array}{c}\text { MBT } \\
\text { Intense } \\
\text { Basic }\end{array}$ & $\begin{array}{c}\text { MBT } \\
\text { Intense } \\
\text { Additional } \\
200 \mathrm{~mm} \mathrm{y}^{-1} \\
\text { infiltration }\end{array}$ \\
\hline Contaminant & \multicolumn{6}{|c|}{ Leachate concentration when equilibrium status is attained } \\
\hline $\begin{array}{l}\text { Antimony } \\
(\mathrm{Sb})\end{array}$ & $\mathrm{X}$ & $\mathrm{X}$ & $\mathrm{X}$ & $x$ & $\mathrm{X}$ & $\mathrm{X}$ \\
\hline Arsenic (As) & AA & 0.0299 & $\mathrm{AB}$ & $\mathrm{AB}$ & $\mathrm{AB}$ & $\mathrm{AB}$ \\
\hline Barium (Ba) & $X$ & $X$ & $X$ & $x$ & $X$ & $X$ \\
\hline $\begin{array}{l}\text { Cadmium } \\
\text { (Cd) }\end{array}$ & $\mathrm{AB}$ & $\mathrm{AB}$ & 0.0183 & $\mathrm{AB}$ & $\mathrm{AB}$ & $\mathrm{AB}$ \\
\hline $\begin{array}{l}\text { Chromium } \\
(\mathrm{Cr})\end{array}$ & 0.4 & 0.802 & $\mathrm{AB}$ & $\mathrm{AB}$ & $\mathrm{AB}$ & $\mathrm{AB}$ \\
\hline Copper $(\mathrm{Cu})$ & 0.417 & $\mathrm{AB}$ & $\mathrm{AB}$ & $\mathrm{AB}$ & $\mathrm{AB}$ & $\mathrm{AB}$ \\
\hline $\begin{array}{l}\text { Mercury } \\
(\mathrm{Hg})\end{array}$ & $\mathrm{AB}$ & $\mathrm{AB}$ & $\mathrm{AB}$ & $\mathrm{AB}$ & $\mathrm{AB}$ & $\mathrm{AB}$ \\
\hline Lead $(\mathrm{Pb})$ & $\mathrm{AB}$ & $\mathrm{AB}$ & 0.112 & 0.126 & $\mathrm{AB}$ & $\mathrm{AB}$ \\
\hline $\begin{array}{l}\text { Molybdenu } \\
\mathrm{m}(\mathrm{Mo})\end{array}$ & $X$ & $X$ & $x$ & $X$ & $x$ & $x$ \\
\hline Nickel (Ni) & 0.255 & 0.254 & 0.256 & 0.267 & $\mathrm{AB}$ & $\mathrm{AB}$ \\
\hline Zinc (Zn) & $\mathrm{AB}$ & $\mathrm{AB}$ & 0.799 & 0.859 & $\mathrm{AB}$ & $\mathrm{AB}$ \\
\hline $\begin{array}{l}\text { Selenium } \\
\text { (Se) }\end{array}$ & $x$ & $X$ & $X$ & $x$ & $x$ & $X$ \\
\hline Fluoride $(F)$ & $x$ & $x$ & $x$ & $X$ & $X$ & $X$ \\
\hline $\begin{array}{l}\text { Sulphate } \\
\left(\mathrm{SO}_{4}\right)\end{array}$ & $\mathrm{AB}$ & $\mathrm{AB}$ & 418.6 & 1098.8 & $\mathrm{AB}$ & $\mathrm{AB}$ \\
\hline Chloride (Cl) & 437.1 & 1139.8 & 433 & 1478.1 & 970.3 & 1381 \\
\hline $\mathrm{NH}_{4}$ & 39.85 & 529.3 & $\mathrm{AB}$ & $\mathrm{AB}$ & $\mathrm{AB}$ & $\mathrm{AB}$ \\
\hline
\end{tabular}

\section{Notes}

MSOR - Mechanically sorted organic residues (generally the fines).

MBT - Mechanical and Biological Treatment (Separation and composting).

Treatment - in this table it relates to the amount or intensity of the composting process.

AA - Groundwater concentration always exceeded WQS hence leachate concentration always above equilibrium status.

AB - Groundwater always below WQS hence leachate always below equilibrium status.

$X$ - No reliable data from UK sites or literature. 
Table 13. Leachate concentrations at equilibrium status for incinerator bottom ash.

\begin{tabular}{|c|c|c|c|c|c|c|}
\hline Waste type & $\begin{array}{c}\text { Raw } \\
\text { bottom ash }\end{array}$ & $\begin{array}{c}\text { Raw } \\
\text { bottom ash }\end{array}$ & Bottom ash & Bottom ash & $\begin{array}{l}\text { Bottom } \\
\text { ash }\end{array}$ & Bottom ash \\
\hline Treatment & None & None & Carbonated & Carbonated & $\begin{array}{l}\text { Acid } \\
\text { treated }\end{array}$ & Acid treated \\
\hline Scenario & Basic & $\begin{array}{l}\text { Additional } \\
500 \mathrm{~mm} \mathrm{y}^{-1} \\
\text { infiltration } \\
\end{array}$ & Basic & $\begin{array}{l}\text { Additional } \\
500 \mathrm{~mm} \mathrm{y}^{-1} \\
\text { infiltration }\end{array}$ & Basic & $\begin{array}{l}\text { Additional } \\
500 \mathrm{~mm} \mathrm{y}^{-1} \\
\text { infiltration }\end{array}$ \\
\hline Contaminant & \multicolumn{6}{|c|}{ Leachate concentration when equilibrium status is attained } \\
\hline Antimony $(\mathrm{Sb})$ & 0.009 & 0.0113 & AA & 0.0092 & AA & 0.006 \\
\hline Arsenic (As) & $\mathrm{AB}$ & $\mathrm{AB}$ & $\mathrm{AB}$ & $\mathrm{AB}$ & $\mathrm{AB}$ & $\mathrm{AB}$ \\
\hline Barium (Ba) & $\mathrm{AB}$ & $\mathrm{AB}$ & $\mathrm{AB}$ & $\mathrm{AB}$ & $\mathrm{AB}$ & $\mathrm{AB}$ \\
\hline Cadmium (Cd) & 0.0087 & $\mathrm{AB}$ & 0.0087 & $\mathrm{AB}$ & 0.0087 & $\mathrm{AB}$ \\
\hline Chromium (Cr) & $\mathrm{AB}$ & $\mathrm{AB}$ & $\mathrm{AB}$ & $\mathrm{AB}$ & $\mathrm{AB}$ & $\mathrm{AB}$ \\
\hline Copper $(\mathrm{Cu})$ & 0.024 & 0.239 & 0.024 & 0.238 & $\mathrm{AB}$ & 0.212 \\
\hline Mercury (Hg) & $X$ & $x$ & $x$ & $X$ & $x$ & $x$ \\
\hline Lead $(\mathrm{Pb})$ & AA & 0.0342 & $\mathrm{AB}$ & $\mathrm{AB}$ & $\mathrm{AB}$ & $\mathrm{AB}$ \\
\hline $\begin{array}{l}\text { Molybdenum } \\
\text { (Mo) }\end{array}$ & 0.209 & 0.213 & 0.193 & 0.232 & 0.197 & 0.251 \\
\hline Nickel (Ni) & $\mathrm{AB}$ & $\mathrm{AB}$ & $\mathrm{AB}$ & $\mathrm{AB}$ & $\mathrm{AB}$ & $\mathrm{AB}$ \\
\hline Zinc (Zn) & $\mathrm{AB}$ & $\mathrm{AB}$ & $\mathrm{AB}$ & $\mathrm{AB}$ & $\mathrm{AB}$ & $\mathrm{AB}$ \\
\hline Selenium (Se) & AA & AA & 0.025 & 0.034 & $\mathrm{AB}$ & $\mathrm{AB}$ \\
\hline Fluoride $(\mathrm{F})$ & $X$ & $x$ & $x$ & $x$ & $x$ & $x$ \\
\hline Sulphate $\left(\mathrm{SO}_{4}\right)$ & $\mathrm{AB}$ & $\mathrm{AB}$ & 357 & 1052 & 357 & 1052 \\
\hline Chloride $(\mathrm{Cl})$ & 722.5 & 985 & 723 & 973.1 & 722.5 & 973.1 \\
\hline $\mathrm{NH}_{4}$ & $\mathrm{AB}$ & $\mathrm{AB}$ & $\mathrm{AB}$ & $\mathrm{AB}$ & $\mathrm{AB}$ & $\mathrm{AB}$ \\
\hline
\end{tabular}

Notes

AA - Groundwater concentration always exceeded WQS hence leachate concentration always above equilibrium status.

AB - Groundwater always below WQS hence leachate always below equilibrium status.

$X$ - No reliable data from UK sites or literature. 